\title{
One-Pot Synthesis of Lithium-Rich Cathode Material with Hierarchical Morphology
}

Kun Luo, Matthew R. Roberts, Rong Hao, Niccoló Guerrini, Emanuela Liberti, Christopher S. Allen, Angus I. Kirkland, and Peter G. Bruce*

Departments of Materials and Chemistry, University of Oxford, Parks Road, Oxford OX1 3PH, United Kingdom

\author{
Supporting Information
}

ABSTRACT: Lithium-rich transition metal oxides, $\mathrm{Li}_{1+x} \mathrm{TM}_{1-x} \mathrm{O}_{2}$ (TM, transition metal), have attracted much attention as potential candidate cathode materials for next generation lithium ion batteries because their high theoretical capacity. Here we present the synthesis of $\mathrm{Li}\left[\mathrm{Li}_{0.2} \mathrm{Ni}_{0.2} \mathrm{Mn}_{0.6}\right] \mathrm{O}_{2}$ using a facile one-pot resorcinol-formaldehyde method. Structural characterization indicates that the material adopts a hierarchical porous morphology consisting of uniformly distributed small pores and disordered large pore structures. The material exhibits excellent electrochemical cycling stability and a good retention of capacity at high rates. The material has been shown to be both advantageous in terms of gravimetric and volumetric capacities over state of the art commercial cathode materials.

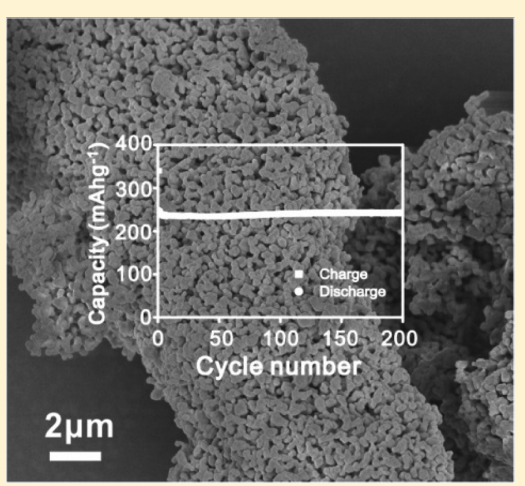

KEYWORDS: Lithium-ion batteries, cathode materials, porous materials, hierarchical morphology

$\mathrm{T}$ he development over the past several decades of the lithium-ion battery has had a huge impact on society and has led to a revolution in portable electronic devices. ${ }^{1}$ However, further improvement in the energy storage of the lithium-ion battery is still required in order to meet the demands of new applications such as electric vehicles. ${ }^{2}$ The energy storage of lithium-ion batteries is primarily restricted by their cathodes, which currently deliver practical capacities of $\sim 190 \mathrm{mAhg}^{-1}$. The lithium-rich layered oxide materials (e.g., Li$\left[\mathrm{Li}_{0.2} \mathrm{Ni}_{0.2} \mathrm{Mn}_{0.6}\right] \mathrm{O}_{2}$ ) are considered promising candidates for the next generation of lithium-ion batteries. ${ }^{4,5}$ These materials offer specific capacities of $\sim 230-280 \mathrm{mAhg}^{-1}$, although their density is lower than nickel-manganese-cobalt cathodes, which means they do not offer such large advantages in terms of energy density. ${ }^{6-9}$ Intricate synthetic preparations have shown that the morphology of the Li rich materials can influence their performance. ${ }^{10-15}$ However, limited control of the morphology can be achieved with the most commonly used synthetic approach that is based on the precipitation of a mixed hydroxide intermediate. This multistep synthesis requires the precipitate to then be combined with the correct amount of $\mathrm{Li}$ carbonate followed by high-temperature calcination and despite its widespread application has resulted in different degrees of structural purity and electrochemical response. The difficulty and importance of synthetic conditions has been highlighted in several papers. ${ }^{16-18}$

Here, we report a simple one-pot synthesis of Li$\left[\mathrm{Li}_{0.2} \mathrm{Ni}_{0.2} \mathrm{Mn}_{0.6}\right] \mathrm{O}_{2}$. The precursor was prepared in a single step by first dissolving the $\mathrm{Li}^{+}, \mathrm{Ni}^{2+}$, and $\mathrm{Mn}^{2+}$ ions in an aqueous solution to which resorcinol and formaldehyde are added to chelate the ions and a polymerization reaction (shown schematically in Figure 1) is then initiated between the resorcinol and formaldehyde suspending the ions in an even distribution throughout the formed polymer. ${ }^{19}$ This was then followed by a high-temperature reaction step. A more detailed description of this process can be found in Methods. The materials prepared in this method forms a desirable hierarchical morphology with $\sim 0.2-0.3 \mu \mathrm{m}$ primary particles agglomerated into $\sim 10-40 \mu \mathrm{m}$ secondary particles. The pores between the primary particles range from $\sim 0.1$ to $0.4 \mu \mathrm{m}$, and larger pores ranging from $\sim 0.5$ to $2.0 \mu \mathrm{m}$ are also present. The resulting material delivers a reversible capacity of $\sim 250 \mathrm{mAhg}^{-1}$ with a remarkably stable cycling behavior and a capacity retention of 99.98\% per cycle over 200 cycles is observed representing meaningful gains both in terms of specific and volumetric capacity.

The composition and structure of $\mathrm{Li}\left[\mathrm{Li}_{0.2} \mathrm{Ni}_{0.2} \mathrm{Mn}_{0.6}\right] \mathrm{O}_{2}$ synthesized by the resorcinol-formaldehyde route was verified by inductively coupled plasma optical emission spectrometry (ICP-OES) analysis and powder X-ray diffraction. The cation ratio was $1.21 / 0.21 / 0.59, \mathrm{Li} / \mathrm{Ni} / \mathrm{Mn}$, consistent with that anticipated from the starting composition. The powder XRD diffraction pattern collected from the $\mathrm{Li}\left[\mathrm{Li}_{0.2} \mathrm{Ni}_{0.2} \mathrm{Mn}_{0.6}\right] \mathrm{O}_{2}$ material is shown in Figure 2. $\mathrm{Li}\left[\mathrm{Li}_{0.2} \mathrm{Ni}_{0.2} \mathrm{Mn}_{0.6}\right] \mathrm{O}_{2}$ is derived from the monoclinic $\mathrm{Li}_{2} \mathrm{MnO}_{3}$ (space group $\mathrm{C} 2 / \mathrm{m}$ ), which may be written as $\mathrm{Li}\left[\mathrm{Li}_{1 / 3} \mathrm{Mn}_{2 / 3}\right] \mathrm{O}_{2}$, highlighting the similarity to a

Received: August 5, 2016

Revised: October 25, 2016

Published: October 28, 2016 


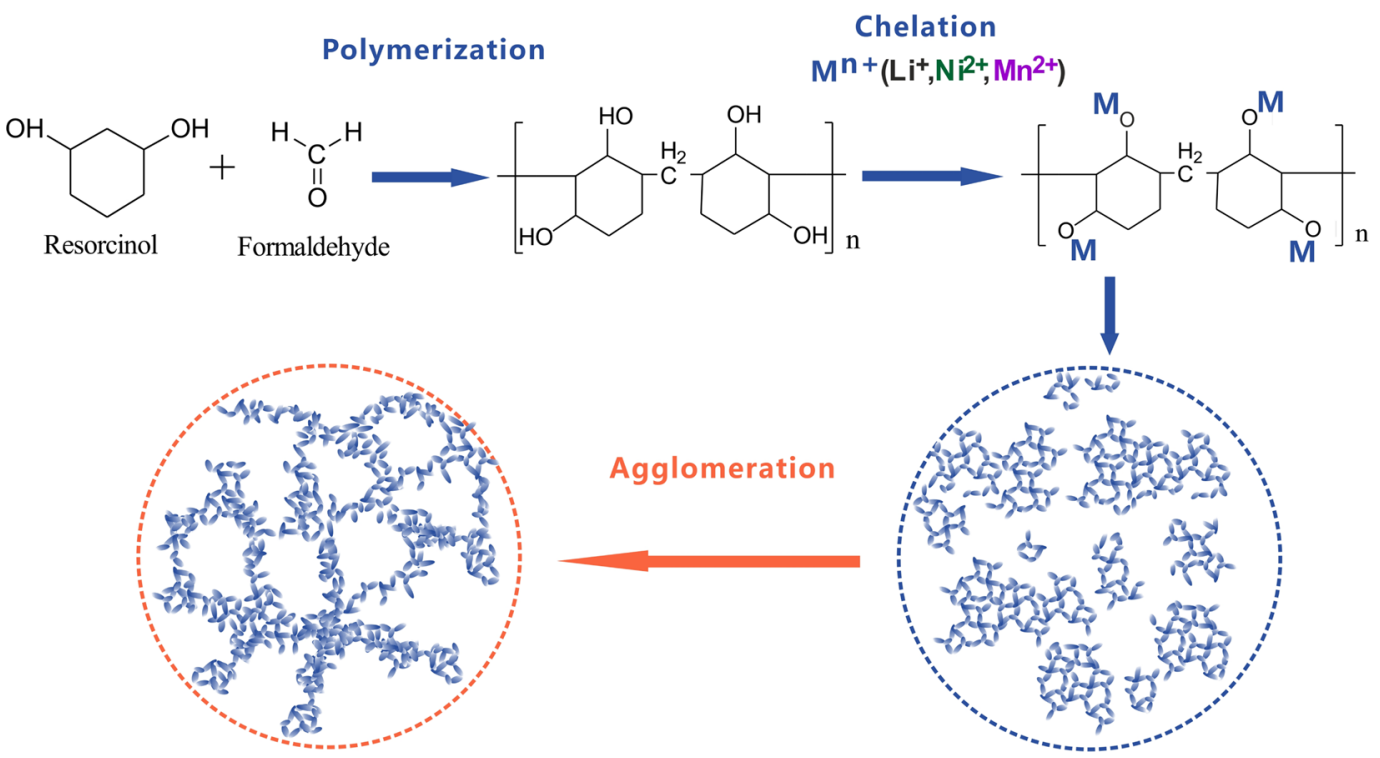

Figure 1. Established mechanism of resorcinol-formaldehyde reaction. ${ }^{19}$

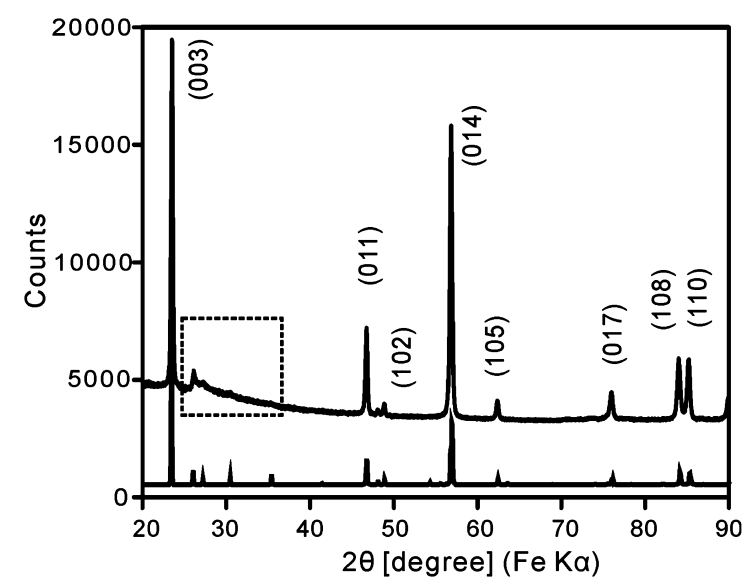

Figure 2. Powder X-ray diffraction pattern of $\mathrm{Li}\left[\mathrm{Li}_{0.2} \mathrm{Ni}_{0.2} \mathrm{Mn}_{0.6}\right] \mathrm{O}_{2}$ synthesized using a resorcinol-formaldehyde reaction (top) and the simulated pattern using a $\mathrm{C} 2 / \mathrm{m}$ structure (bottom).
$\mathrm{LiCoO}_{2}$ layered structure with alternating $\mathrm{Li}$ layers and $\left[\mathrm{Li}_{1 / 3} \mathrm{Mn}_{2 / 3}\right]$ layers. By substituting $x=0.2 \mathrm{Ni}$ into $\mathrm{Li}\left[\mathrm{Li}_{1 / 3-2 x / 3} \mathrm{Mn}_{2 / 3-x / 3} \mathrm{Ni}_{x}\right] \mathrm{O}_{2}$, the composition of the material studied here is obtained. The transition metal layers in $\mathrm{Li}\left[\mathrm{Li}_{1 / 3} \mathrm{Mn}_{2 / 3}\right] \mathrm{O}_{2}$ exhibit short-range ordering of the $\mathrm{Li}^{+}$and $\mathrm{Mn}^{4+}$ and such short-range order persists in the Li$\left[\mathrm{Li}_{0.2} \mathrm{Ni}_{0.2} \mathrm{Mn}_{0.6}\right] \mathrm{O}_{2}$ compound, as is evident in the powder $\mathrm{X}$ ray diffraction pattern shown in Figure 2 where diffraction peaks appear at positions similar to that of the $\mathrm{Li}_{2} \mathrm{MnO}_{3} \cdot{ }^{7,20-23}$ The broadening of the peaks in the $2 \theta$ range of 26 to $36^{\circ}$ (Fe $\mathrm{K}_{\alpha}$ ) is associated with the rotation between layers that restricts the long-range correlation between slabs along $c$-axis. ${ }^{24-26}$

The local cation ordering in the transition metal layers of the material was characterized further using scanning transmission electron microscopy (STEM). Figure 3a shows a high-angle annular dark field (HAADF) image of a pristine particle. The contrast in this imaging mode scales approximately to $\mathrm{Z}^{1.7}$, thus brightest columns indicate the position of the cations in the transition metal layers, while lighter atoms, like lithium and oxygen, are not visible. Three main variants of the monoclinic
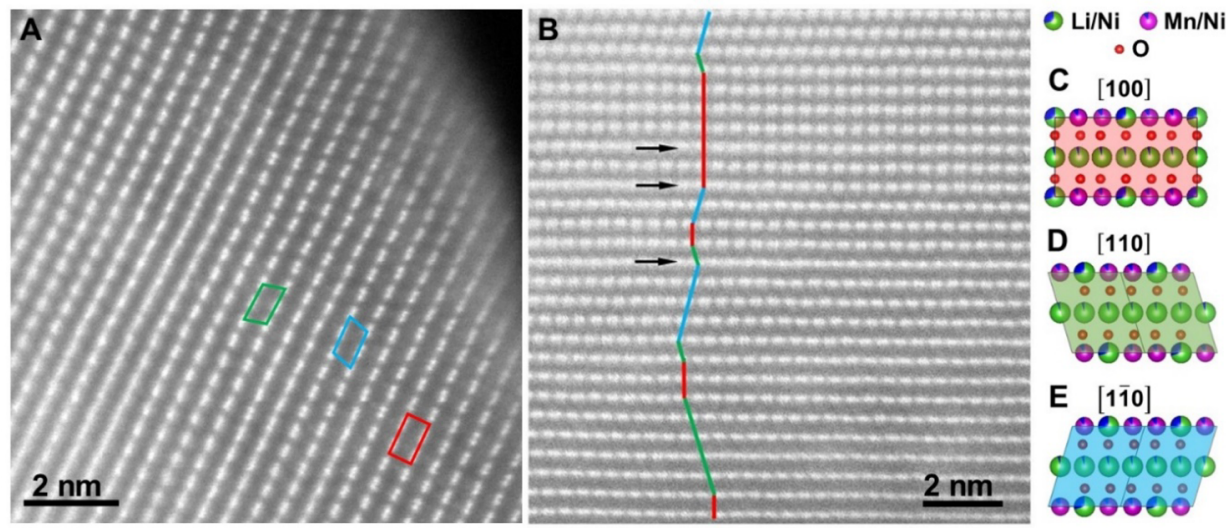

Figure 3. Experimental HAADF images, showing the structure of the as-prepared $\mathrm{Li}\left[\mathrm{Li}_{0.2} \mathrm{Ni}_{0.2} \mathrm{Mn}_{0.6}\right] \mathrm{O}_{2}$ material, consisting of the different stacking of three main projections of the monoclinic unit cell, the [100] in red, the [110] in green and the [110] in blue (a). The crystal domains of these three main variants are shown in (b) by colored lines. Flips along the (001) planes, reflection twins (flips between [110] and [1 $\overline{10}]$ ) and disordered transition metal layers (arrows) are generally observed. The unit cells in the different orientations are shown in (c-e). 

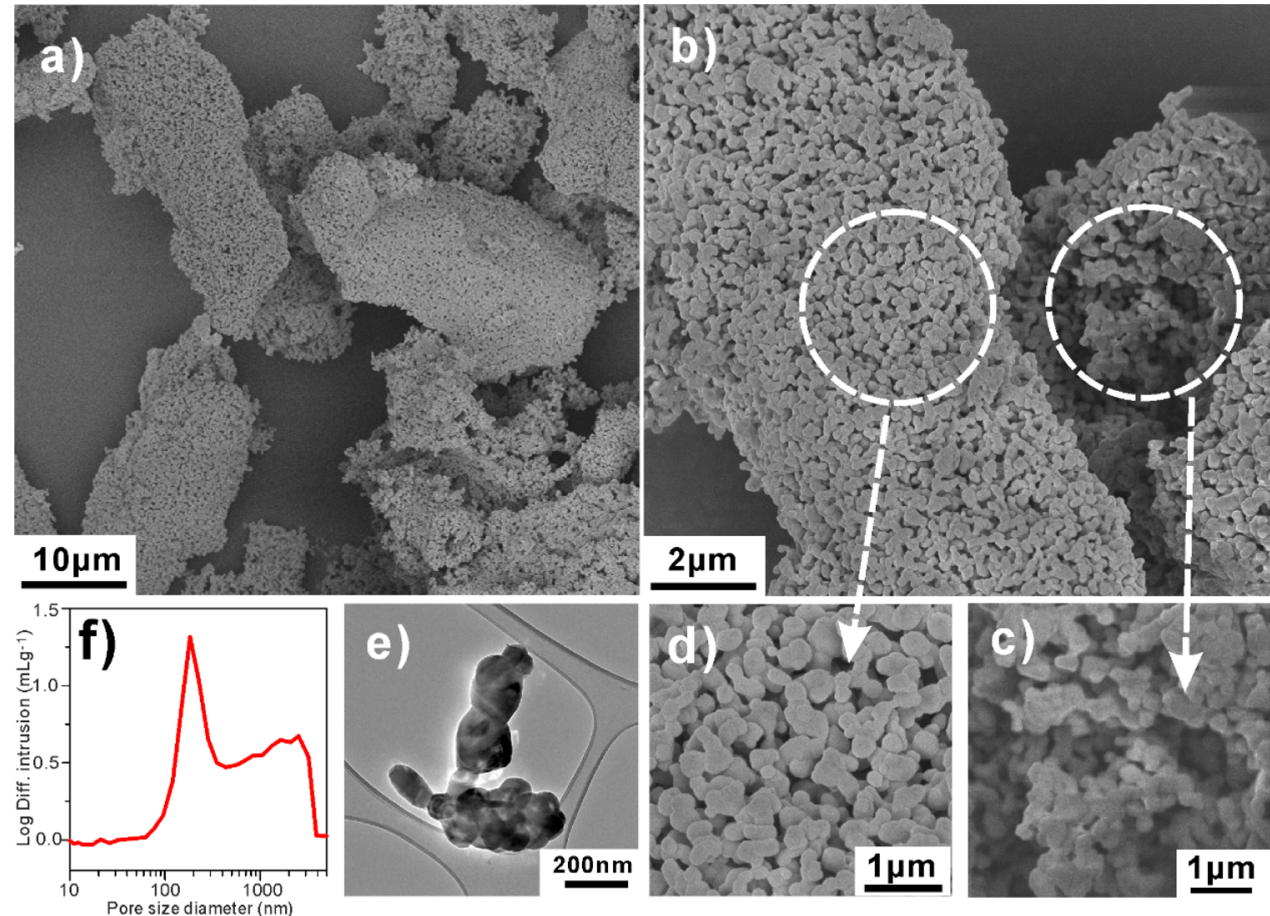

Figure 4. Morphological studies of porous $\mathrm{Li}\left[\mathrm{Li}_{0.2} \mathrm{Ni}_{0.2} \mathrm{Mn}_{0.6}\right] \mathrm{O}_{2}$ material. (a-d) SEM images. (e) TEM image. (f) Macroscopic pore-size distribution obtained by mercury intrusion porosimetry.
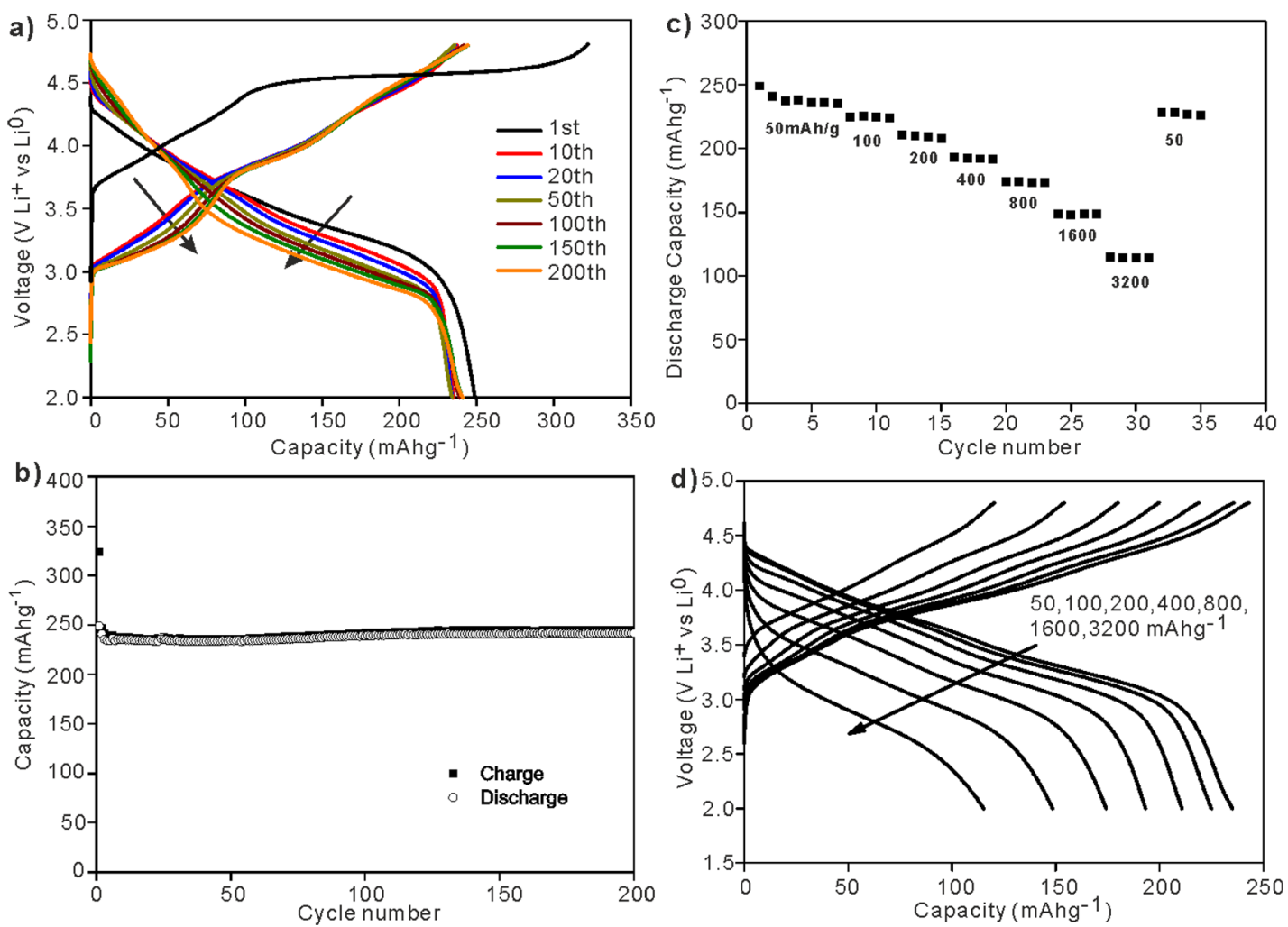

Figure 5. Electrochemical behaviors of porous $\mathrm{Li}\left[\mathrm{Li}_{0.2} \mathrm{Ni}_{0.2} \mathrm{Mn}_{0.6}\right] \mathrm{O}_{2}$. (a) Charge/discharge profiles at different cycles. (b) Cycling performance up to 200 cycles at $50 \mathrm{~mA} \mathrm{~g}^{-1}$ at $30{ }^{\circ} \mathrm{C}$. (c) Rate performance of $\mathrm{Li}\left[\mathrm{Li}_{0.2} \mathrm{Ni}_{0.2} \mathrm{Mn}_{0.6}\right] \mathrm{O}_{2}$ at $30{ }^{\circ} \mathrm{C}$. (d) Discharge curves at various rates after charging to 4.8 $\mathrm{V}$ at $50 \mathrm{~mA} \mathrm{~g}^{-1}$.

region ( $\mathrm{C} 2 / \mathrm{m}$ space group) constitute the material's structure, corresponding to the $[100],[110]$, and $[1 \overline{1} 0]$ projections of the monoclinic unit cell (structural models in Figure $3 \mathrm{c}-\mathrm{e}$, respectively). The cation ordering in TM layer observed for the contrast in Figure $3 \mathrm{a}$ places $\mathrm{Li}^{+} / \mathrm{Ni}^{2+}$ at the $2 \mathrm{~b}$ sites and $\mathrm{Mn}^{4+} / \mathrm{Ni}^{2+}$ at the $4 \mathrm{~g}$ sites in the $\mathrm{C} 2 / \mathrm{m}$ space group (as sketched in Figure $3 \mathrm{c}-\mathrm{e})$, consistent with the result from neutron powder diffraction data shown in the Supporting Information. 
As Figure $3 \mathrm{~b}$ shows, the crystal domains consisting of the three monoclinic variants not only vary in size but also stack along the direction perpendicular to the transition metal layers without long-range order. Furthermore, flips of the domains, as well as transition metal-rich defects (arrows in Figure 3b), are observed, which lower the periodicity. This lack of long-range order (along the $c$-direction) is consistent with broad peaks in the $2 \theta$ range of 26 to $36^{\circ}\left(\mathrm{Fe}_{\alpha}\right)$ observed from the $\mathrm{X}$-ray powder diffraction pattern (Figure 2), and agrees well with previous studies on the local structure of lithium-rich materials. $^{26,27}$ Therefore, we conclude that the composition and crystal structure of $\mathrm{Li}\left[\mathrm{Li}_{0.2} \mathrm{Ni}_{0.2} \mathrm{Mn}_{0.6}\right] \mathrm{O}_{2}$ synthesized using the one-pot method is in good agreement with those materials prepared previously.

The morphology of the $\mathrm{Li}\left[\mathrm{Li}_{0.2} \mathrm{Ni}_{0.2} \mathrm{Mn}_{0.6}\right] \mathrm{O}_{2}$ material was examined using scanning electron microscopy (SEM) and transmission electron microscopy (TEM). As shown in the SEM and TEM images (Figure $4 \mathrm{a}-\mathrm{e}$ ), the material adopts a hierarchical morphology with primary particles of $\sim 0.2-0.3 \mu \mathrm{m}$ (Figure $4 \mathrm{~d}, \mathrm{e}$ ) that are fused together at the edges to form the larger secondary particles of $\sim 10-40 \mu \mathrm{m}$ (Figure $4 \mathrm{a}, \mathrm{b}$ ). The primary particles have a relatively narrow size distribution. The pores between the primary particles range from $\sim 0.1$ to $0.4 \mu \mathrm{m}$ (Figure $4 \mathrm{~d}$ ), and larger pores ranging from $\sim 0.5$ to $2.0 \mu \mathrm{m}$ are also present (Figure 4c). The hierarchical porosity was further probed using mercury intrusion porosimetry. The pore size distribution in Figure $4 \mathrm{f}$ shows a sharp peak at $\sim 0.2 \mu \mathrm{m}$ and a broad peak at $\sim 2.0 \mu \mathrm{m}$, consistent with our SEM observations from Figure $4 \mathrm{c}, \mathrm{d}$. The total intrusion volume is $1.4 \mathrm{~mL} \mathrm{~g}^{-1}$ and the total pore area is $6.5 \mathrm{~m}^{2} / \mathrm{g}$. Note that this value is comparable to materials with a similar hierarchical structure $\left(2.5-5.6 \mathrm{~m}^{2} / \mathrm{g}\right)^{11,15}$ but significantly smaller than the nanoparticulate materials (e.g., $65 \mathrm{~m}^{2} / \mathrm{g}$ for nanowire material). ${ }^{13}$

The electrochemical behavior of the $\mathrm{Li}\left[\mathrm{Li}_{0.2} \mathrm{Ni}_{0.2} \mathrm{Mn}_{0.6}\right] \mathrm{O}_{2}$ material is shown in Figure 5a. The voltage increases almost linearly in the initial stage of charge, followed by a plateau at approximately $4.5 \mathrm{~V}$ and a sloping region up to $4.8 \mathrm{~V}$. After the first charge, the subsequent discharge and charge follow a different path, which continues thereafter and with a continuous drift of the potential to lower voltages on cycling. The behavior is consistent with results for comparable lithium rich electrodes reported previously. The capacity retention for the hierarchical $\mathrm{Li}\left[\mathrm{Li}_{0.2} \mathrm{Ni}_{0.2} \mathrm{Mn}_{0.6}\right] \mathrm{O}_{2}$ material, cycled with a charge/discharge rate of $50 \mathrm{~mA} \mathrm{~g}^{-1}$, is shown in Figure $5 \mathrm{~b}$. The first charge capacity was $\sim 322 \mathrm{mAh} \mathrm{g}^{-1}$ followed by a first discharge capacity of $\sim 250 \mathrm{mAh} \mathrm{g}^{-1}$. The material exhibits good capacity retention on cycling and retains a reversible capacity of $\sim 241 \mathrm{mAh} \mathrm{g}^{-1}$ even after 200 cycles, corresponding to a capacity retention of $99.98 \%$ per cycle.

The rate performance at discharge rates from 50 to $3200 \mathrm{~mA}$ $\mathrm{g}^{-1}$ between 2.0 and $4.8 \mathrm{~V}$ after charging to $4.8 \mathrm{~V}$ at $50 \mathrm{~mA} \mathrm{~g}^{-1}$ on each cycle is presented in Figure 5c. The material exhibits a discharge capacity of $\sim 241 \mathrm{mAh} \mathrm{g}^{-1}$ at $50 \mathrm{~mA} \mathrm{~g}^{-1}$ and $\sim 160$ $\mathrm{mAh} \mathrm{g}^{-1}$ at $1600 \mathrm{~mA} \mathrm{~g}^{-1}$, corresponding to a discharge of $<10$ min. The capacity recovers substantially on returning to the lower rate of $50 \mathrm{~mA} \mathrm{~g}^{-1}$ consistent with the polarization being reversible. The charge and discharge profiles at various rates after the cell was charged to $4.8 \mathrm{~V}$ at $50 \mathrm{~mA} \mathrm{~g}^{-1}$ on each cycle are also shown in Figure 5d.

The mechanism by which charge compensation is achieved in lithium-rich materials such as $\mathrm{Li}\left[\mathrm{Li}_{0.2} \mathrm{Ni}_{0.2} \mathrm{Mn}_{0.6}\right] \mathrm{O}_{2}$ is significantly different from conventional materials. ${ }^{6-8,28-33}$ While $\sim 125 \mathrm{mAhg}^{-1}$ is accounted for by oxidation of the $\mathrm{Ni}$ (i.e., $\mathrm{Ni}^{2+}$ to $\mathrm{Ni}^{4+}$ ) in the first charge, no further transition metal oxidation occurs. ${ }^{31,34}$ The additional charge extracted is attributed to loss of oxygen from the lattice and redox reactions on the oxygen. ${ }^{30,35,36}$ These unconventional mechanisms of charge compensation have received considerable attention recently and have now been demonstrated in 3, 4, and 5d transition metal oxides. ${ }^{24,30,37,38}$ We have shown elsewhere, using operando electrochemical mass spec of ${ }^{18} \mathrm{O}$ labeled lithium-rich material that $\sim 15 \%$ of charge extracted up to $4.8 \mathrm{~V}$ is due to $\mathrm{O}$ loss, which reacts with the typical organic carbonate electrolyte to evolve $\mathrm{CO}_{2}$ on the $4.5 \mathrm{~V}$ plateau with direct $\mathrm{O}_{2}$ evolution dominating from the end of plateau to $4.8 \mathrm{~V}$. Soft Xray absorption spectroscopy, X-ray absorption near edge structure spectroscopy (XANES), Raman, and resonant inelastic X-ray scattering (RIXS) demonstrate that the dominant charge compensation involves the formation of localized electron-hole states on the oxygen ions coordinated by $\mathrm{Mn}^{4+} / \mathrm{Li}^{+} .{ }^{35,36}$ The details are given in references 35 and 36 .

Generally, the Li rich cathodes exhibit poor rate performance and capacity fading. The capacity retention on cycling and the rate performance reported for the material synthesized by the one-pot method compares well with some of the best results in the literature of $\mathrm{Li}$ rich cathodes. It should be noted that the rate testing was performed with an electrode which had a mass loading of $\sim 70 \mathrm{~g} \mathrm{~m}^{-2}$. It has been often proved necessary to coat the particles of $\mathrm{Li}$ rich cathode materials with nonelectrochemical active materials (e.g., $\mathrm{AlF}_{3}$ ) stabilizing the surfaces at the relatively high potentials used. ${ }^{4}$ Alternatively, $\mathrm{FePO}_{4}$ coating or porous $\mathrm{Co}_{3} \mathrm{O}_{4}$ coating on $\mathrm{Li}$ rich cathode materials has also proved effective to decrease the irreversibility on cycling by forming intermediate surface phase such as $\mathrm{Li}_{x} \mathrm{FePO}_{4}$ or $\mathrm{Li}_{x} \mathrm{CoO}_{y}{ }^{39,40}$ Here there is no explicit coating. The hierarchical morphology provides a material with a relatively low surface area compared with nanoparticles, which others have shown minimizes the side reactions between electrolyte and electrode, suppressing the O loss on the surface and improving the cycling stability. ${ }^{11,15}$ We have also shown that a similar synthesis approach to the formation of $\mathrm{LiNi}_{0.5} \mathrm{Mn}_{1.5} \mathrm{O}_{4}{ }^{41}$ and $\mathrm{Li}\left[\mathrm{Ni}_{1 / 3} \mathrm{Mn}_{1 / 3} \mathrm{Co}_{1 / 3}\right] \mathrm{O}_{2}{ }^{42}$ also improved cycling stability.

One problem encountered with the Li rich cathodes is their relatively low tap density. Dahn and co-workers ${ }^{43}$ have used an indirect but simple measurement of tap density involving the following steps: (1) Press a pellet of the material at $48000 \mathrm{psi}$; (2) calculate the density of the pressed pellet; (3) take $90 \%$ of the calculated value to convert gravimetric to volumetric energy densities. In this study, we followed this method to compare the density of the present hierarchical material with several commercial materials. The hierarchical material was pressed into a pellet under $5 \times 10^{5} \mathrm{psi}$. The density of our porous $\mathrm{Li}\left[\mathrm{Li}_{0.2} \mathrm{Ni}_{0.2} \mathrm{Mn}_{0.6}\right] \mathrm{O}_{2}$ pellet was calculated to be $\sim 2934 \mathrm{~g} \mathrm{~L}^{-1}$ ( $\sim 704 \mathrm{Ah} \mathrm{L}^{-1}$, assuming a practical capacity $\left.240 \mathrm{mAh} \mathrm{g}^{-1}\right)$. This value may be compared with the commercial Ni-rich $\mathrm{Li}\left[\mathrm{Ni}_{0.5} \mathrm{Co}_{0.2} \mathrm{Mn}_{0.3}\right] \mathrm{O}_{2}\left(\sim 3643 \mathrm{~g} \mathrm{~L}^{-1}, \sim 575 \mathrm{Ah} \mathrm{L}^{-1}\right.$, assuming a practical capacity $\left.158 \mathrm{mAh} \mathrm{g}^{-1}\right)$ and $\mathrm{LiFePO}_{4}\left(\sim 2178 \mathrm{~g} \mathrm{~L}^{-1}\right.$, $327 \mathrm{Ah} \mathrm{L}^{-1}$, assuming a practical capacity $\left.150 \mathrm{mAh} \mathrm{g}^{-1}\right)(\mathrm{MTI}$ corporation). This shows that an approximately $22 \%$ increase in cathode volumetric capacity may be anticipated in addition to an approximate $30 \%$ gain in gravimetric energy density.

In conclusion, $\mathrm{Li}\left[\mathrm{Li}_{0.2} \mathrm{Ni}_{0.2} \mathrm{Mn}_{0.6}\right] \mathrm{O}_{2}$ has been synthesized by a simple one-pot reaction using a resorcinol-formaldehyde method. The material adopts a hierarchical porous morphology that has been characterized using SEM, TEM, and mercury- 
intrusion porosimetry. The material exhibits good capacity retention and rate performance with excellent gravimetric (241 $\left.\mathrm{mAh} \mathrm{g}^{-1}\right)$ and volumetric $\left(\sim 704 \mathrm{Ah} \mathrm{L}^{-1}\right)$ energy densities at 50 $\mathrm{mA} \mathrm{g}^{-1}$. The method reported in this paper can also be extended to the synthesis of other electrode materials in batteries.

Methods. Sample Preparation. The porous Li$\left[\mathrm{Li}_{0.2} \mathrm{Ni}_{0.2} \mathrm{Mn}_{0.6}\right] \mathrm{O}_{2}$ sample was synthesized using a resorcinol-formaldehyde gel method. ${ }^{42}$ Stoichiometric amounts of $\mathrm{LiCH}_{3} \mathrm{COO} \cdot 2 \mathrm{H}_{2} \mathrm{O}$ (99.0\%, Aldrich), $\mathrm{Ni}\left(\mathrm{CH}_{3} \mathrm{COO}\right)_{2} \cdot 4 \mathrm{H}_{2} \mathrm{O}$ (99.0\%, Aldrich), and $\mathrm{Mn}\left(\mathrm{CH}_{3} \mathrm{COO}\right)_{2} \cdot 4 \mathrm{H}_{2} \mathrm{O}$ (99.0\%, Fluka) were dissolved in $50 \mathrm{~mL}$ of distilled water containing $0.1 \mathrm{~mol}$ of resorcinol (99.0\%, Fluka), $0.15 \mathrm{~mol}$ of formaldehyde (Fluka $36.5 \%$ in water, methanol-stabilized), and $0.25 \mathrm{mmol}$ of $\mathrm{Li}_{2} \mathrm{CO}_{3}$ (99.0\%, Fluka). The resulting solution contained a $5 \mathrm{~mol} \%$ excess of $\mathrm{Li}$. The mixture was then dried at $90{ }^{\circ} \mathrm{C}$ overnight, followed by calcination at $900{ }^{\circ} \mathrm{C}$ for $15 \mathrm{~h}$ to obtain the final material.

Structural Characterization. Powder X-ray diffraction (XRD) was carried out using a STOE STADI/P diffractometer operating in transmission mode using an $\mathrm{Fe} \mathrm{K}_{\alpha}$ radiation source. Neutron powder diffraction data was collected using the Polaris diffractometer at the ISIS neutron source, U.K. Rietveld profile refinements were performed using the GSAS suite of programs. ${ }^{44}$ Morphological studies were conducted using a JEOL JSM-5600 SEM and a JEOL ARM200F probe-corrected STEM, operating at $200 \mathrm{kV}$ using a probe convergence semiangle of $22 \mathrm{mrad}$ and a calibrated $34-52 \mathrm{mrad}$ collection angle for HAADF images. Elemental analysis was carried out by ICP-OES using a PerkinElmer Optima 7300DV ICP-OES. Mercury-intrusion porosimetry (AutoPore IV 9400, Micromeritics Instrument Corporation) was carried out to evaluate the porosity.

Electrochemical Tests. The working electrodes consisted of 80 wt \% active material, $10 \mathrm{wt} \%$ Super P carbon, and $10 \mathrm{wt} \%$ polytetrafluoroethylene (PTFE) binder. The working electrode mass was typically $\sim 5 \mathrm{mg}$. A Li metal counter electrode was used with a $1 \mathrm{M} \mathrm{LiPF}_{6}$ in ethylene carbonate/dimethyl carbonate $(1: 1 \mathrm{v} / \mathrm{v})$ (Merck) as electrolyte. Materials were assembled into coin cells (details) in an argon filled glovebox. Electrochemical measurements were carried out using a Biologic VMP3 potentiostat.

\section{ASSOCIATED CONTENT}

\section{S Supporting Information}

The Supporting Information is available free of charge on the ACS Publications website at DOI: 10.1021/acs.nanolett.6b03296.

Neutron powder diffraction data (PDF)

\section{AUTHOR INFORMATION}

\section{Corresponding Author}

*E-mail: peter.bruce@materials.ox.ac.uk.

\section{Notes}

The authors declare no competing financial interest.

Research data has been deposited in ORA-data at DOI: 10.5287/bodleian:eyOnYxqRD.

\section{ACKNOWLEDGMENTS}

P.G.B. is indebted to the EPSRC, including the SUPREGEN program and the European Union Seventh Framework Programme under Grant Agreement 312483-ESTEEM2 for financial support. The authors are grateful to Ron Smith for the collection of neutron diffraction data.

\section{REFERENCES}

(1) Goodenough, J. B.; Kim, Y. Chem. Mater. 2010, 22 (3), 587-603.

(2) Bruce, P. G.; Scrosati, B.; Tarascon, J. M. Angew. Chem., Int. Ed. 2008, 47 (16), 2930-2946.

(3) Aricò, A. S.; Bruce, P.; Scrosati, B.; Tarascon, J. M.; Van Schalkwijk, W. Nat. Mater. 2005, 4 (5), 366-377.

(4) Sun, Y. K.; Lee, M. J.; Yoon, C. S.; Hassoun, J.; Amine, K.; Scrosati, B. Adv. Mater. 2012, 24 (9), 1192-1196.

(5) Yu, H. J.; Zhou, H. S. J. Phys. Chem. Lett. 2013, 4 (8), 12681280.

(6) Lu, Z. H.; MacNeil, D. D.; Dahn, J. R. Electrochem. Solid-State Lett. 2001, 4 (11), A191-A194.

(7) Lu, Z. H.; Dahn, J. R. J. Electrochem. Soc. 2002, 149 (7), A815A822.

(8) Johnson, C. S.; Kim, J. S.; Lefief, C.; Li, N.; Vaughey, J. T.; Thackeray, M. M. Electrochem. Commun. 2004, 6 (10), 1085-1091.

(9) Thackeray, M. M.; Johnson, C. S.; Vaughey, J. T.; Li, N.; Hackney, S. A. J. Mater. Chem. 2005, 15 (23), 2257-2267.

(10) Wang, D. P.; Belharouak, I.; Zhou, G. W.; Amine, K. Adv. Funct. Mater. 2013, 23 (8), 1070-1075.

(11) Chen, L.; Su, Y. F.; Chen, S.; Li, N.; Bao, L. Y.; Li, W. K.; Wang, Z.; Wang, M.; Wu, F. Adv. Mater. 2014, 26 (39), 6756-6760.

(12) Wei, G. Z.; Lu, X.; Ke, F. S.; Huang, L.; Li, J. T.; Wang, Z. X.; Zhou, Z. Y.; Sun, S. G. Adv. Mater. 2010, 22 (39), 4364-4367.

(13) Kim, M. G.; Jo, M.; Hong, Y. S.; Cho, J. Chem. Commun. 2009, 2, 218-220.

(14) Ma, G.; Li, S.; Zhang, W. X.; Yang, Z. H.; Liu, S. L.; Fan, X. M.; Chen, F.; Tian, Y.; Zhang, W. B.; Yang, S. H.; Li, M. Angew. Chem., Int. Ed. 2016, 55 (11), 3667-3671.

(15) Oh, P.; Myeong, S.; Cho, W.; Lee, M. J.; Ko, M.; Jeong, H. Y.; Cho, J. Nano Lett. 2014, 14 (10), 5965-5972.

(16) Wang, D. P.; Belharouak, I.; Zhou, G. W.; Amine, K. J. Electrochem. Soc. 2013, 160 (5), A3108-A3112.

(17) Zhou, F.; Zhao, X. M.; van Bommel, A.; Rowe, A. W.; Dahn, J. R. Chem. Mater. 2010, 22 (3), 1015-1021.

(18) Manthiram, A.; Knight, J. C.; Myung, S. T.; Oh, S. M.; Sun, Y. K. Adv. Energy Mater. 2016, 6 (1), 1501010.

(19) Al-Muhtaseb, S. A.; Ritter, J. A. Adv. Mater. 2003, 15 (2), 101114.

(20) Bareno, J.; Lei, C. H.; Wen, J. G.; Kang, S. H.; Petrov, I.; Abraham, D. P. Adv. Mater. 2010, 22 (10), 1122-1127.

(21) Lu, Z. H.; Chen, Z. H.; Dahn, J. R. Chem. Mater. 2003, 15 (16), 3214-3220.

(22) Gu, M.; Genc, A.; Belharouak, I.; Wang, D. P.; Amine, K.; Thevuthasan, S.; Baer, D. R.; Zhang, J. G.; Browning, N. D.; Liu, J.; Wang, C. M. Chem. Mater. 2013, 25 (11), 2319-2326.

(23) Meng, Y. S.; Ceder, G.; Grey, C. P.; Yoon, W. S.; Jiang, M.; Breger, J.; Shao-Horn, Y. Chem. Mater. 2005, 17 (9), 2386-2394.

(24) Koga, H.; Croguennec, L.; Mannessiez, P.; Menetrier, M.; Weill, F.; Bourgeois, L.; Duttine, M.; Suard, E.; Delmas, C. J. Phys. Chem. C 2012, 116 (25), 13497-13506.

(25) Koga, H.; Croguennec, L.; Menetrier, M.; Mannessiez, P.; Weill, F.; Delmas, C. J. Power Sources 2013, 236, 250-258.

(26) Shukla, A. K.; Ramasse, Q. M.; Ophus, C.; Duncan, H.; Hage, F.; Chen, G. Y. Nat. Commun. 2015, 6, 8711.

(27) Jarvis, K. A.; Deng, Z. Q.; Allard, L. F.; Manthiram, A.; Ferreira, P. J. Chem. Mater. 2011, 23 (16), 3614-3621.

(28) Thackeray, M. M.; Kang, S. H.; Johnson, C. S.; Vaughey, J. T.; Benedek, R.; Hackney, S. A. J. Mater. Chem. 2007, 17 (30), 31123125.

(29) Armstrong, A. R.; Holzapfel, M.; Novak, P.; Johnson, C. S.; Kang, S. H.; Thackeray, M. M.; Bruce, P. G. J. Am. Chem. Soc. 2006, 128 (26), 8694-8698.

(30) Koga, H.; Croguennec, L.; Menetrier, M.; Douhil, K.; Belin, S.; Bourgeois, L.; Suard, E.; Weill, F.; Delmas, C. J. Electrochem. Soc. 2013, 160 (6), A786-A792. 
(31) Koga, H.; Croguennec, L.; Menetrier, M.; Mannessiez, P.; Weill, F.; Delmas, C.; Belin, S. J. Phys. Chem. C 2014, 118 (11), 5700-5709.

(32) Castel, E.; Berg, E. J.; El Kazzi, M.; Novak, P.; Villevieille, C. Chem. Mater. 2014, 26 (17), 5051-5057.

(33) Yabuuchi, N.; Yoshii, K.; Myung, S. T.; Nakai, I.; Komaba, S. J. Am. Chem. Soc. 2011, 133 (12), 4404-4419.

(34) Ito, A.; Sato, Y.; Sanada, T.; Hatano, M.; Horie, H.; Ohsawa, Y. J. Power Sources 2011, 196 (16), 6828-6834.

(35) Luo, K.; Roberts, M. R.; Hao, R.; Guerrini, N.; Pickup, D. M.; Liu, Y. S.; Edstrom, K.; Guo, J. H.; Chadwick, A. V.; Duda, L. C.; Bruce, P. G. Nat. Chem. 2016, 8 (7), 684-691.

(36) Luo, K.; Roberts, M. R.; Guerrini, N.; Tapia-Ruiz, N.; Hao, R.; Massel, F.; Pickup, D. M.; Ramos, S.; Liu, Y. S.; Guo, J.; Chadwick, A. V.; Duda, L. C.; Bruce, P. G. J. Am. Chem. Soc. 2016, 138 (35), 112118.

(37) Sathiya, M.; Rousse, G.; Ramesha, K.; Laisa, C. P.; Vezin, H.; Sougrati, M. T.; Doublet, M. L.; Foix, D.; Gonbeau, D.; Walker, W.; Prakash, A. S.; Ben Hassine, M.; Dupont, L.; Tarascon, J. M. Nat. Mater. 2013, 12 (9), 827-835.

(38) McCalla, E.; Abakumov, A. M.; Saubanere, M.; Foix, D.; Berg, E. J.; Rousse, G.; Doublet, M. L.; Gonbeau, D.; Novak, P.; Van Tendeloo, G.; Dominko, R.; Tarascon, J. M. Science 2015, 350 (6267), 15161521.

(39) Wang, F. X.; Xiao, S. Y.; Li, M. X.; Wang, X. W.; Zhu, Y. S.; Wu, Y. P.; Shirakawa, A.; Peng, J. J. Power Sources 2015, 287, 416-421.

(40) Wang, F. X.; Chang, Z.; Wang, X. W.; Wang, Y. F.; Chen, B. W.; Zhu, Y. S.; Wu, Y. P. J. Mater. Chem. A 2015, 3 (9), 4840-4845.

(41) Shaju, K. M.; Bruce, P. G. Dalton T 2008, 40, 5471-5475.

(42) Shaju, K. M.; Bruce, P. G. Adv. Mater. 2006, 18 (17), 23302334.

(43) Jouanneau, S.; Eberman, K. W.; Krause, L. J.; Dahn, J. R. J. Electrochem. Soc. 2003, 150 (12), A1637-A1642.

(44) Larson, A. C.; Von Dreele, R. B. Los Alamos Natl. Lab. Rep. 2000, 86-748. 